\title{
Psychological determinants of life satisfaction in women undergoing infertility treatment
}

\begin{abstract}
BACKGROUND
Infertility treatment is a long-term process, spread out over months, or even years, and carries no guarantee of success. It generates an incessant state of uncertainty which becomes a chronic state of psychological discomfort. Each stage of treatment may become a source of more trouble. Women deciding to undergo infertility treatment are exposed to many negative feelings concerning different aspects of their life.
\end{abstract}

\section{PARTICIPANTS AND PROCEDURE}

The present study was an attempt to understand psychological determinants of life satisfaction in women undergoing infertility treatment. The study group included 470 women treated for infertility.

\section{RESULTS}

Patients perceiving more social support in general, as well as more of the support types used in the study, i.e. emotional, instrumental, informational and institutional support, and support from family and friends, have better self-esteem, higher acceptance of their infertility, higher satisfaction with life, higher hope as an emotional state, and lower levels of anxiety and depression. Three negative emotional states, i.e. anxiety, depression and irritation, are predictors influencing (lowering) life satisfaction of women struggling with infertility. The strongest of these predictors is depression, which is also a factor lowering the acceptance of one's own infertility. The conducted analyses revealed that predictors influencing the life satisfaction of patients treated for infertility are self-esteem and acceptance of one's own infertility (apart from the aforementioned emotional state - anxiety, depression, irritation). It was found that the higher the self-esteem and acceptance of one's own infertility, the higher was the satisfaction with life.

\section{CONCLUSIONS}

Knowledge of these determinants is extremely valuable for medical personnel conducting treatments, because, according to many studies, the psychological state of women suffering from procreation problems is connected not only with effectiveness of the used procedures, but mostly with psychological support provided for such women.

\section{KEY WORDS}

infertility; satisfaction of life; acceptance 


\section{BACKGROUND}

Infertility treatment is a long-term process, spread out over months, or even years, and carries no guarantee of success. It generates an incessant state of uncertainty which becomes a chronic state of psychological discomfort. Each stage of treatment may become a source of more trouble. Women deciding to have infertility treatment are exposed to many negative feelings concerning different aspects of their life (Domar, Seibel, \& Benson, 1990; Boivin \& Takefman, 1995; Verhaak et al., 2001; Greil, Shreffer, Schmist, \& McQuillan, 2011; Cousineau \& Domar, 2007; Bielawska-Batorowicz, 2006; Bidzan, 2010; Donarelli et al., 2012; Domar et al., 2012).

Reactions to the state of infertility are manifold. Difficulties with conceiving a baby arouse anxiety usually only a few months after the moment the efforts to have a baby were undertaken. Menning (1980; Bielawska-Batorowicz, 1991; Kalus, 2002; Trzeciakowska, 2003; Bidzan, 2010) described emotional problems of infertile marriages and underlined the fact that most couples react to the diagnosis in a similar way. The first reaction usually was astonishment and disbelief, especially if the pregnancy was carefully planned. Ignoring and rejecting the diagnosis is also a common reaction. It is also a dangerous one, as it delays treatment or even makes it impossible to start it, which is disastrous in the case of older women whose optimal procreative period is coming to an end. Denial usually precedes the time when couples in a way adapt to the situation. It is at that time when couples usually consider the possibility of asking for help. In some couples the denial is so strong that it actually is the last reaction to the infertility diagnosis. However, in the case of most couples, the next stage is anger and annoyance directed at the physician, therapeutic procedures and their outcomes. Infertile partners are also often struck with a feeling of guilt. He or she usually looks for the reasons of infertility in various past events (e.g. abortion, extramarital sexual contacts, use of contraceptives or postponing a decision to start a family). Other examples of common behaviors displayed by infertile couples are: avoiding contact with other people, especially those having children, hiding their own feelings, and hiding the infertility itself. Such behaviors foster their sense of social isolation, increase the stress resulting from infertility, and affect their partner relations.

The longer the period of unsuccessful infertility treatment, the more negative the emotional reactions (mostly depression) experienced by women undergoing such treatment are (Bielawska-Batorowicz, 1990, 1991; cf. studies of Kee, Jung, \& Lee, 2000; cf. Khademi, Alleyassin, Aghahosseini, Ramezanzadeh, \& Abhari, 2005; cf. Sbaragli et al., 2008; cf. Lund, Sejbaek, Christensen, \& Schmidt, 2009; Baldar-Felskov et al., 2012; Lopes \& Leal, 2012). According to some authors, infertile women often feel unaccepted by society, which triggers anxiety and a sense of guilt (Greil, Shreffer, Schmist, \& McQuillan, 1997; Wischamann, Stammer, Scherg, Gerhard, \& Verres, 2001; Bidzan, 2010; Whiteford \& Gonzales, 1995; Mindes, Ingram, Kliewer, \& James, 2003; Weiss, Mateju, \& Urbanek, 2004; Noorbala et al., 2008; Lopes \& Leal, 2012). Often in the course of infertility new personality traits, mostly neurotic ones, are revealed in women (Bidzan, 2010; Weiss et al., 2004; Noorbala et al., 2008; cf. De Berardis et al., 2014). Observed emotional reactions included frustration and anger (Valentine, 1986, after: Holas, Radziwoń, \& Wójtowicz, 2002), as well as lowered self-esteem (Platt et al., 1973, after: Holas et al., 2002; Bidzan, 2010; Klimek, 1995; Mindes, Ingram, Kliewer, \& James, 2003). Lowered self-esteem affected the women's contacts with their partners, physicians, as well as other persons, which often caused problems in their interpersonal relations (Berg \& Wilson, 1990; Bell, 1981, after: Holas et al., 2002; cf. Bidzan, 2010; Lopes \& Leal, 2012). Other emotional symptoms included stress (Valentine, 1986, after: Holas et al., 2002; cf. Domar et al., 2009), chronic fatigue, and obsessive thoughts (Valentine, 1986, after: Holas et al., 2002; Noorbala, Ramezanzadeh, Abedinia, \& Naghizadeh, 2009; De Berardis et al., 2014). Eating disorders (cf. Sbaragli, 2008; cf. Freizinger, Franko, Dacey, Okun, \& Domar, 2010; De Berardis et al., 2014), as well as alcohol and drug abuse (Trzeciakowska, 2003; De Berardis et al., 2014), may also appear.

According to Mindes et al. (2003) the depression symptoms pattern which is usually found in infertile women (cf. Nelson, Shindel, Naughton, Ohebshalom, \& Mulhall, 2008) can be described as an emotional see-saw vacillating between optimism and hope on one side, and desperation and depression episodes on the other. Women welcome each menstrual period with hope of conceiving a baby, while each failure makes them revert to pessimism and hopelessness (cf. Alesi, 2005; Dembińska, 2013, 2014).

Researchers analyzing causes of depression in infertile women emphasize one of the key factors conditioning the development of such causes, i.e. the feeling of loss. Mahlstedt (1985, after: Holas et al., 2002) listed spheres affected by this loss:

a) disintegration of partnership (or constant fear that it may happen);

b) deterioration of one's own image / losing acceptance of one's body, health and attractiveness;

c) lower spontaneity and satisfaction with sexual life;

d) losing prestige and status in other people's eyes, because having children has an important social and cultural role;

e) losing self-confidence;

f) lower self-trust and sense of control of one's life;

g) losing dreams and hopes.
Psychological determinants of life satisfaction in women undergoing infertility treatment 
Aleksandra Anna Dembińska
Intensity and time of treatment place a psychological burden on the couple undergoing treatment which results in changes in the perception of reality. The partners develop a cognitive vision of their own illness and create its subjective image. This process consists in determining one's own knowledge, experiences, cause and nature of the illness. It is believed that a cognitive vision of experienced disorders has a regulatory function and is one of the factors determining the patients' behaviors. Types of reactions resulting from the illness and medical attention are described as secondary (Łuczak-Wawrzyniak \& Pisarski, 1997). Moreover, women suffering from infertility often cognitively focus on procreation (Beisert, 1992; Bidzan, 2010). They concentrate almost solely on their problems and attempts to get pregnant, while most, if not all, other matters previously considered important become subordinated to this goal. Meetings with their family, friends and colleagues are no longer very attractive or important. People experiencing the frustration stemming from the need to become a parent move away from others and their social contacts become sparser. This escape from others may also result from the sense of one's low self-esteem and lack of self-acceptance (Beisert, 1992; Bidzan, 2010).

Emotional and cognitive problems may be compounded by sexual conflicts and disorders. Many of them have their roots in improper experiencing of emotions, while these emotions affect the functioning of the nervous system and endocrine system. Usually, sexual problems are further aggravated by prolonged unsuccessful efforts to conceive a baby (Kainz, 2001). Ramezanzadeh, Aghssa, Jafarbadi and Zayeri (2006) evaluated the level of sexual desire and satisfaction in infertile couples. The results indicated that sexual desire was lower in $41.50 \%$ of cases, while sexual satisfaction was lower in $52.50 \%$ of cases when compared to the reported levels before infer- tility was diagnosed. Therefore, long-term infertility and yearning for a child had a negative influence on sexual satisfaction. Studies indicate that in infertile couples sexual problems occur much more often in women than in men (Nelson et al., 2008).

The research outcomes adduced above reveal the diversity of consequences of suffering from infertility. This is something that people interacting with infertile women, especially healthcare workers, should take into account, as it may help to overcome many possible communication problems (cf. Benyamini, Gozlan, \& Kokia, 2005).

The study conducted was an attempt to understand psychological determinants of life satisfaction in women undergoing infertility treatment. It was based on a previously prepared analysis of psychological costs of dealing with life crisis in women suffering from infertility (Dembińska, 2014). Using the concept of psychological costs (Ratajczak, 1989, $1998,2000,2001,2007)$ made it possible to examine the issue of experiencing infertility while presenting its multi-faceted nature. Psychological costs are emotional states with a definite content. They correlate with preventive strategies, as they appeal to the subject for actions with a relevant content in order to prevent an excessive resource loss. Thus, those costs serve an important regulatory function and influence the "resource" management - which makes them increase one's effectiveness of coping with difficult situations. They appear in successive stages of the coping process and invite a sober reflection when it is over.

The psychological costs selected during the pilot study may be identified in each stage of the coping process. The psychological costs were grouped (Table 1), which made it possible to choose the variables to use in this study. These variables are: self-esteem; perception of social support; emotional state: depression, anxiety, irritation, hope, acceptance of one's

Table 1

Psychological costs selected in the pilot study vs. variables used in the planned study

\begin{tabular}{|c|c|c|c|}
\hline Self-esteem & $\begin{array}{c}\text { Perception of social } \\
\text { support }\end{array}$ & $\begin{array}{c}\text { Attitude towards one's } \\
\text { infertility }\end{array}$ & Emotional state \\
\hline Loss of a sense of dignity & Sense of loneliness & $\begin{array}{c}\text { Feeling of life disorgani- } \\
\text { zation }\end{array}$ & Fear and anxiety \\
\hline \multirow[t]{5}{*}{ Loss of self-esteem } & $\begin{array}{l}\text { Deterioration of partner } \\
\text { relations }\end{array}$ & Sense of shame & Sadness \\
\hline & & $\begin{array}{c}\text { Obsessive thinking } \\
\text { about willingness to have } \\
\text { a child }\end{array}$ & $\begin{array}{l}\text { Lability of hope } \\
\text { as a state }\end{array}$ \\
\hline & & Sense of guilt & Sense of tiredness \\
\hline & & & $\begin{array}{c}\text { Sense of emotional } \\
\text { see-saw }\end{array}$ \\
\hline & & & Anger, annoyance \\
\hline
\end{tabular}


own infertility and satisfaction with life. A pilot study became the basis for formulating hypotheses involving associations between variables.

\section{PARTICIPANTS AND PROCEDURE}

The study group included 470 women treated for infertility (age 20-45). The study group was recruited by the association for the treatment of infertility and to promote adoption 'Our Stork'. Women were treated for infertility in different clinics and by different doctors. The studies conducted were anonymous and voluntary, and the person tested had the opportunity to discontinue participation in them at any time. It was also possible to contact the researcher after participating in the study to discuss concerns about the study - from which some participants benefited. The study does not violate accepted principles of ethical research.

The sociodemographic variables that differentiated the study group were: treatment time, time since diagnosis, treatment method, infertility factor and type of infertility (Table 2).

The following tools were used:

1. Acceptance of one's Own Infertility Scale (AOIS) - an original tool based on the Acceptance of Illness Scale (AIS). Reliability of this scale measured by Cronbach's $\alpha$ is .84 . Because of the peculiarity of infertility as an illness, i.e. in most cases it is hardly experienced outside of procreation activities, some of the AIS items were removed and replaced with questions that concerned experiencing infertility. High scores on the AOIS scale represent worse acceptance of one's own infertility, while low scores are achieved by people who are better at dealing with their condition.

2. HDS-M Scale [Zigmond \& Snaith; Polish version by: Majkowicz, de Walden-Gałuszko and Chojnacka-Szawłowska (Majkowicz \& ChojnackaSzawłowska, 1994)] measuring anxiety, depression and aggression/irritation.

3. Scale for Assessment of Hope as an Emotional State (an original tool). Hope as an emotional state at the same time encompasses the fear that things are going to get worse and the yearning for improvement (Lazarus, 1994). It is a bimodal characteristic spanning from joy to sadness. When the yearning to achieve a desirable goal becomes a certainty, the hope turns into joy, while when this target moves away, the hope becomes despair. Hope is measured here by means of an original questionnaire allowing one to determine the level of hope now and a month ago (cf. Dembińska, 2013).

4. The Satisfaction with Life Scale (SWLS) prepared by Diener, Emmons, Larson, and Griffin (1985). Polish version by Juczyński (2001). Satisfaction with life is defined as a general assessment of the quality of life in relation to the criteria set by oneself (Shin \& Johanson, 1978). Subjective
Psychological determinants of life satisfaction in women undergoing infertility treatment

Table 2

Characteristics of the subject group

\begin{tabular}{|c|c|c|c|}
\hline Variables & & $N=1,044$ & $\%$ \\
\hline \multirow{3}{*}{ Treatment time } & Less than a year & 161 & 34.30 \\
\hline & $2-5$ years & 238 & 50.60 \\
\hline & Over 5 years & 71 & 15.10 \\
\hline \multirow{4}{*}{ Treatment method } & Pharmacological diagnosis/treatment & 225 & 47.90 \\
\hline & Insemination & 75 & 16.00 \\
\hline & IVF/ICSI & 138 & 29.40 \\
\hline & Becoming an egg recipient & 32 & 6.80 \\
\hline \multirow{3}{*}{$\begin{array}{l}\text { Time since } \\
\text { diagnosis }\end{array}$} & Less than a year & 94 & 20.00 \\
\hline & $2-5$ years & 278 & 59.10 \\
\hline & Over 5 years & 98 & 20.90 \\
\hline \multirow{4}{*}{ Infertility factor } & Female infertility & 150 & 31.90 \\
\hline & Male infertility & 93 & 19.80 \\
\hline & Infertility in both partners & 104 & 22.10 \\
\hline & Undiagnosed infertility & 123 & 26.20 \\
\hline \multirow{2}{*}{ Type of infertility } & Primary & 421 & 89.60 \\
\hline & Secondary & 49 & 10.40 \\
\hline
\end{tabular}


well-being comprises three elements: satisfaction with life level, positive feelings and lack of negative feelings (Diener, 1984; Pavot \& Diener, 1993). The assessment of satisfaction with life is the result of comparison of one's situation with the standards set by oneself. If the result of the comparison is satisfactory, the feeling of satisfaction ensues.

5. Self-Esteem Scale (SES) by Rosenberg (Polish version: Dzwonkowska, Lachowicz-Tabaczek, \& Łaguna, 2008). Self-esteem is a relatively constant predisposition understood as a conscious (positive or negative) attitude toward oneself.

6. The original Scale of Perception of Social Support in Infertility takes into account emotional, informational and instrumental support from one's family and friends and medical personnel. Perception of Social Support is the individual's ability to perceive the supportive, i.e. desired, nature of other people's behaviors. The individual compares the desired support with the support received. It is a type of interaction or exchange taken up by one or two parties, and resulting in an exchange of emotions, information, action tools and material goods (Kahn, 1979; Sęk, 1986, 1993). Reliability of this scale measured by Cronbach's $\alpha$ is .81 .

The study results were subjected to a statistical analysis. To carry out this analysis, the following methods were used: the Spearman's correlation coefficient, the Kruskal-Wallis test and regression analysis. The significance level of $p<.05$ was used to determine the existence of statistically significant differences or relations.

\section{RESULTS}

The author looked for relations between variables included in the study. The statistical analysis revealed a positive correlation between perception of social support and its types (emotional, instrumental, material, family and institutional), on the one hand, and self-esteem, satisfaction with life and hope, on the other. It also revealed a negative correlation with levels of anxiety and depression as well as acceptance of one's own infertility (because of the reversed scale in the questionnaire measuring this item, this relation means that higher social support is connected with better acceptance of one's own infertility). No relations were found between perception of social support (and its types) and the irritation variable (Table 3).

Analysis of correlations between the variables included in the study (Table 4) also indicated positive relations between the following variables:

- self-esteem with satisfaction with life, irritation, hope as an emotional state and age,

- satisfaction with life with hope and age,

- irritation with hope,
- levels of anxiety and depression (and both these variables) with acceptance of one's own infertility. Negative relations were identified between the following variables:

- acceptance of one's own infertility with self-esteem, satisfaction with life, hope and age,

- anxiety and depression with self-esteem, satisfaction with life, hope and age,

- the level of depression is negatively correlated with irritation reported by women taking part in the study.

The author also searched for relations between psychological variables and sociodemographic variables used to characterize women taking part in the study. The statistical analysis indicated that the only variable giving statistically significant results depending on the infertility treatment method was the perception of social support (Table 5) - the more advanced the treatment method, the more positive was the perception of social support. The highest level of social support perception was reported by women using in vitro fertilization (IVF) methods and intracytoplasmic sperm injection (ICSI), while the lowest was reported by patients undergoing diagnosis or pharmacology treatment of infertility. The analysis showed no significant differences in the levels of other psychological variables, i.e. self-esteem, satisfaction with life, acceptance of one's own infertility, or emotional state (anxiety, depression, irritation, hope), in groups selected on the basis of various treatment methods.

The analysis of relations between the infertility factor and other psychological variables (Table 6) indicated that, similarly to the "method of treatment" sociodemographic variable, statistically significant differences appear between patient groups depending on the perception of social support. The highest perceived social support level was reported by women treated for infertility diagnosed in both partners, while the lowest was reported by the ones in whose case the reason for infertility was not identified (idiopathic infertility). The same relation was true also for the level of perceived institutional support. When it comes to the perception of material support and support from family and friends, the highest level was reported by women in whose case infertility affected both partners. However, the lowest level was reported by patients treated for infertility because of the male factor. No statistically significant differences were found between other psychological variables and the infertility factor.

A sociodemographic variable influencing levels of more psychological variables was the infertility type (Table 7). It shows statistically significant relations with the perceived level of social support, acceptance of one's own infertility, hope as an emotional state, and irritation. Women experiencing primary infertility perceive more social support and are less irritated than women struggling with secondary infertility, 


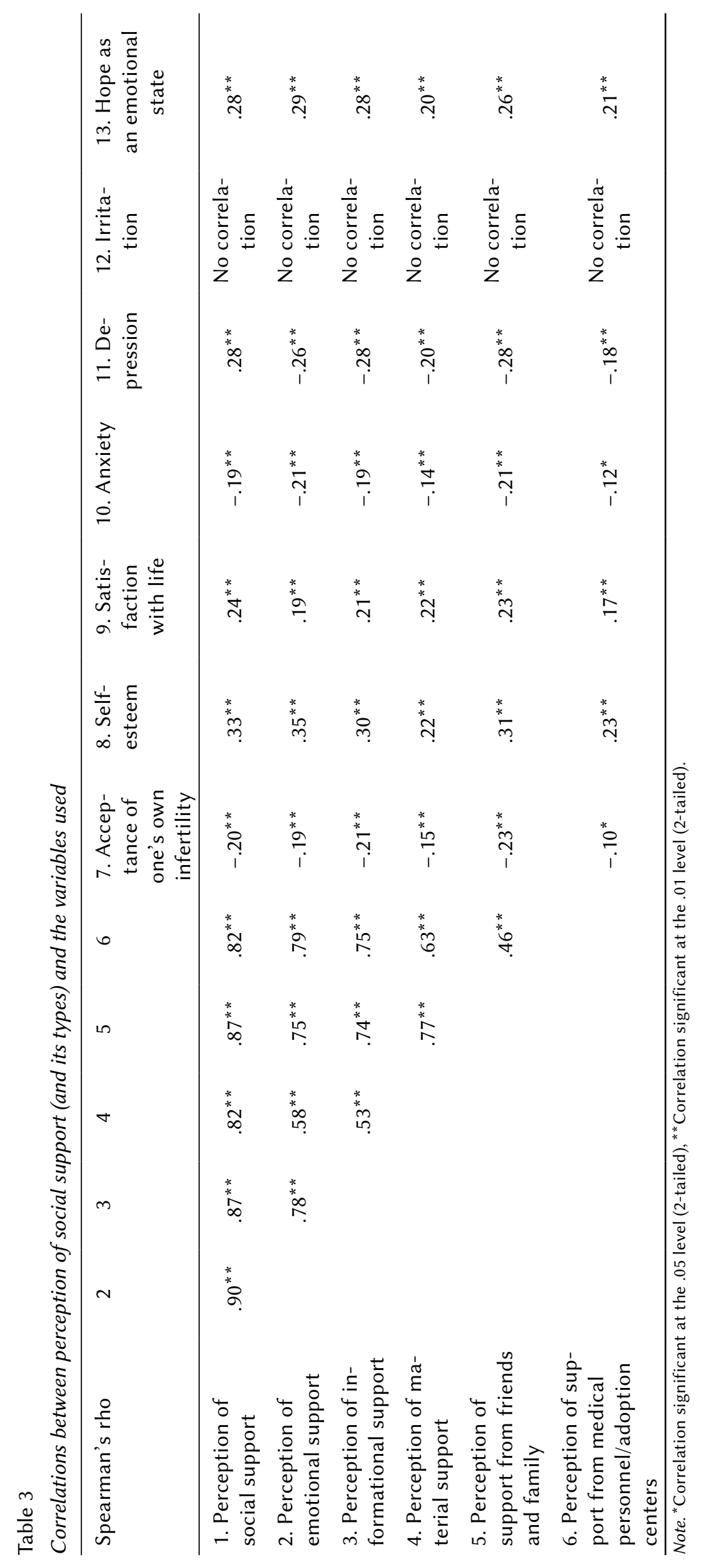

Psychological determinants of life satisfaction in women undergoing infertility treatment 
Table 4

Correlation between variables included in the study

\begin{tabular}{|c|c|c|c|c|c|c|c|}
\hline Spearman's rho & 2 & 3 & 4 & 5 & 6 & 7 & 8. Age \\
\hline $\begin{array}{l}\text { 1. Acceptance of one's own } \\
\text { infertility }\end{array}$ & $-.61^{* *}$ & $-.43^{* *}$ & $.45^{* *}$ & $.58^{* *}$ & $\begin{array}{l}\text { No correla- } \\
\text { tion }\end{array}$ & $-.36^{* *}$ & $-.12^{* *}$ \\
\hline 2. Self-esteem & & $.45^{* *}$ & $-.45^{* *}$ & $-.61^{* *}$ & $.132^{* *}$ & $.36^{* *}$ & $.15^{* *}$ \\
\hline 3. Satisfaction with life & & & $-.43^{* *}$ & $-.57^{* *}$ & $\begin{array}{l}\text { No correla- } \\
\text { tion }\end{array}$ & $.24^{* *}$ & $.12^{*}$ \\
\hline 4. Anxiety & & & & $.66^{* *}$ & $\begin{array}{l}\text { No correla- } \\
\text { tion }\end{array}$ & $-.24^{* *}$ & $-.20 * *$ \\
\hline 5. Depression & & & & & $-.11^{*}$ & $-.37^{* *}$ & $-.12^{* *}$ \\
\hline 6. Irritation & & & & & & $.17^{* *}$ & $\begin{array}{l}\text { No cor- } \\
\text { relation }\end{array}$ \\
\hline 7. Hope as an emotional state & & & & & & & $\begin{array}{l}\text { No cor- } \\
\text { relation }\end{array}$ \\
\hline
\end{tabular}

Note. ${ }^{*}$ Correlation significant at the .05 level (2-tailed), ${ }^{* *}$ Correlation significant at the .01 level (2-tailed).

Table 5

Results of the Kruskal-Wallis test for perception of social support depending on the infertility treatment method used

\begin{tabular}{|c|c|c|c|c|c|c|}
\hline Variables & $\begin{array}{l}\text { Infertility treatment } \\
\text { method }\end{array}$ & $\begin{array}{l}N= \\
470\end{array}$ & $\begin{array}{l}\text { Mean } \\
\text { range }\end{array}$ & $\chi^{2}$ & $D f$ & $\begin{array}{l}\text { Asymptotic } \\
\text { significance }\end{array}$ \\
\hline \multirow{4}{*}{$\begin{array}{l}\text { Perception of } \\
\text { social support }\end{array}$} & $\begin{array}{c}\text { Diagnosis/pharmacology } \\
\text { treatment }\end{array}$ & 225 & 218.06 & \multirow{4}{*}{8.87} & \multirow{4}{*}{3} & \multirow{4}{*}{.031} \\
\hline & Insemination & 75 & 254.75 & & & \\
\hline & IVF/ICSI & 138 & 260.41 & & & \\
\hline & Egg cell donation & 32 & 227.86 & & & \\
\hline
\end{tabular}

but they are at the same time characterized by lower acceptance of one's own infertility and lower hope.

The analysis of the variables depending on the time since infertility diagnosis and time of treatment provided no statistically significant results $(p>.05)$ between the levels of all the variables included in the study (self-esteem, satisfaction with life, emotional state, acceptance of one's own infertility).

To estimate the influence of independent variables on the dependent variable - satisfaction with life - the method of stepwise forward regression was used (Table 8). The regression model turned out to be statistically significant and explained approximately $40 \%$ of the dependent variable. The predictors included in the model that had a significant directly proportional influence on the satisfaction with life were perception of social support and self-esteem. An inversely proportional influence was revealed for the following predictors: acceptance of one's own infertility, anxiety, depression, and irritation. The following variables were excluded from the model: perception of social support, perception of support friends and family, and hope as an emotional state.
As in the previous case, the method of stepwise forward regression analysis was used to estimate the influence of independent variables (predictors) on the second dependent variable - acceptance of one's own infertility (Table 9). The regression model turned out to be statistically significant and explained approximately $44.00 \%$ of the dependent variable. Only one predictor included in the model - depression had a directly proportional significant influence on acceptance of one's own infertility. Predictors that influenced it in an inversely proportional way were satisfaction with life and self-esteem. The following variables were not included in the model: perception of social support, perception of support from family and friends, and hope as an emotional state.

\section{DISCUSSION}

The analysis of relations between variables and of the influence exerted by the determinants of life satisfaction in women treated for infertility revealed many dependencies that are interesting from the point of 
Table 6

Results of the Kruskal-Wallis test for perception of social support and its types depending on the infertility factor

\begin{tabular}{|c|c|c|c|c|c|c|}
\hline Variables & Infertility factor & $\begin{array}{l}N= \\
470\end{array}$ & $\begin{array}{l}\text { Mean } \\
\text { range }\end{array}$ & $\chi^{2}$ & $d f$ & $\begin{array}{l}\text { Asymptotic } \\
\text { significance }\end{array}$ \\
\hline \multirow{4}{*}{$\begin{array}{l}\text { Perception of social } \\
\text { support }\end{array}$} & Female infertility & 150 & 247.54 & \multirow{4}{*}{9.29} & \multirow{4}{*}{3} & \multirow{4}{*}{.026} \\
\hline & Male infertility & 93 & 223.58 & & & \\
\hline & Both partners infertile & 104 & 258.83 & & & \\
\hline & Idiopathic & 123 & 210.10 & & & \\
\hline \multirow{4}{*}{$\begin{array}{l}\text { Perception of material } \\
\text { support }\end{array}$} & Female infertility & 150 & 250.90 & \multirow{4}{*}{11.03} & \multirow{4}{*}{3} & \multirow{4}{*}{.012} \\
\hline & Male infertility & 93 & 206.91 & & & \\
\hline & Both partners infertile & 104 & 258.31 & & & \\
\hline & Idiopathic & 123 & 219.04 & & & \\
\hline \multirow{4}{*}{$\begin{array}{l}\text { Perception of sup- } \\
\text { port from family and } \\
\text { friends }\end{array}$} & Female infertility & 150 & 244.66 & \multirow{4}{*}{10.23} & \multirow{4}{*}{3} & \multirow{4}{*}{.017} \\
\hline & Male infertility & 93 & 205.85 & & & \\
\hline & Both partners infertile & 104 & 262.57 & & & \\
\hline & Idiopathic & 123 & 223.86 & & & \\
\hline \multirow{4}{*}{$\begin{array}{l}\text { Perception of support } \\
\text { from medical person- } \\
\text { nel }\end{array}$} & Female infertility & 150 & 246.42 & \multirow{4}{*}{8.52} & \multirow{4}{*}{3} & \multirow{4}{*}{.036} \\
\hline & Male infertility & 93 & 243.34 & & & \\
\hline & Both partners infertile & 104 & 248.70 & & & \\
\hline & Idiopathic & 123 & 205.09 & & & \\
\hline
\end{tabular}

Table 7

Results of the Kruskal-Wallis test for individual variables depending on the infertility type

\begin{tabular}{|c|c|c|c|c|c|c|}
\hline Variables & Infertility type & $\begin{array}{l}N= \\
470\end{array}$ & $\begin{array}{l}\text { Mean } \\
\text { range }\end{array}$ & $\chi^{2}$ & $d f$ & $\begin{array}{l}\text { Asymptotic } \\
\text { significance }\end{array}$ \\
\hline \multirow{2}{*}{$\begin{array}{l}\text { Perception of social } \\
\text { support }\end{array}$} & Primary & 421 & 239.11 & \multirow{2}{*}{5.20} & \multirow{2}{*}{1} & \multirow{2}{*}{.023} \\
\hline & Secondary & 49 & 204.50 & & & \\
\hline \multirow{2}{*}{$\begin{array}{l}\text { Acceptance of one's } \\
\text { own infertility }\end{array}$} & Primary & 421 & 241.00 & \multirow{2}{*}{6.65} & \multirow{2}{*}{1} & \multirow{2}{*}{.010} \\
\hline & Secondary & 49 & 188.20 & & & \\
\hline \multirow{2}{*}{$\begin{array}{l}\text { Hope as an emotional } \\
\text { state }\end{array}$} & Primary & 421 & 230.78 & \multirow{2}{*}{4.93} & \multirow{2}{*}{1} & \multirow{2}{*}{.026} \\
\hline & Secondary & 49 & 276.05 & & & \\
\hline \multirow{2}{*}{ Irritation } & Primary & 421 & 231.66 & \multirow{2}{*}{4.10} & \multirow{2}{*}{1} & \multirow{2}{*}{.043} \\
\hline & Secondary & 49 & 268.48 & & & \\
\hline
\end{tabular}

view of psychological help offered to such women. Patients perceiving more social support in general, as well as more of the support types used in the study, i.e. emotional, instrumental, informational and institutional support, and support from family and friends, have better self-esteem, higher acceptance of one's own infertility, higher satisfaction with life, higher hope as an emotional state and lower levels of anxiety and depression. This variable also showed statistically significant differences when analyzed along with sociodemographic variables. One of them was the method of infertility treatment - the more advanced the method, the higher the level of social support perceived by the patients. Similar conclusions were reached in previous research of the author. Treatment with more advanced assisted reproduction methods results in more contacts with medical personnel. Because of the fact that infertility treatment often includes periods apparently bringing no results (e.g. waiting for several monthly cycles for the effects of a medical procedure), women perceive the medical procedures implementation time as a time inten-
Psychological determinants of life satisfaction in women undergoing infertility treatment 
Table 8

Overview of stepwise forward regression model - dependent variable: satisfaction with life

\begin{tabular}{|c|c|c|c|c|c|}
\hline \multicolumn{6}{|c|}{$\begin{array}{c}R=.63 ; R^{2}=.40 ; \text { Adjusted } R^{2}=.39 \\
F=27.64, p<.001\end{array}$} \\
\hline & \multicolumn{2}{|c|}{ Standardized rates } & \multicolumn{2}{|c|}{ Non-standardized rates } & \multirow[t]{2}{*}{$p$} \\
\hline & $B$ & $\begin{array}{c}\text { Standard } \\
\text { error }\end{array}$ & $\beta$ & $t$ & \\
\hline Y-intercept & 28.95 & 3.03 & & 9.55 & $<.001$ \\
\hline Emotional support & -0.34 & 0.21 & -.11 & -1.66 & .098 \\
\hline Informational support & 0.12 & 0.20 & .04 & 0.60 & .546 \\
\hline Material support & 0.29 & 0.13 & .11 & 2.18 & .030 \\
\hline Support from medical personnel & 0.05 & 0.14 & .27 & 0.39 & .700 \\
\hline Acceptance of one's own infertility & -0.08 & 0.04 & -.10 & -1.98 & .048 \\
\hline Self-esteem & 0.21 & 0.07 & .16 & 3.07 & .002 \\
\hline Anxiety & -0.17 & 0.08 & -.10 & -2.07 & .040 \\
\hline Depression & -0.52 & 0.09 & -.35 & -6.08 & $<.001$ \\
\hline Irritation & -1.01 & 0.27 & -.14 & -3.78 & $<.001$ \\
\hline
\end{tabular}

Table 9

Overview of stepwise forward regression model - dependent variable: acceptance of one's own infertility

\begin{tabular}{|c|c|c|c|c|c|}
\hline \multicolumn{6}{|c|}{$\begin{array}{c}R=.68 ; R^{2}=.46 ; \text { Adjusted } R^{2}=.45 \\
F=35.63, p<.001\end{array}$} \\
\hline & \multicolumn{2}{|c|}{ Standardized rates } & \multicolumn{2}{|c|}{ Non-standardized rates } & \multirow[t]{2}{*}{$p$} \\
\hline & $B$ & $\begin{array}{l}\text { Standard } \\
\text { error }\end{array}$ & $\beta$ & $t$ & \\
\hline Y-intercept & 27.55 & 3.47 & & 7.94 & $<.001$ \\
\hline Informational support & -0.32 & 0.38 & -.86 & -0.83 & .407 \\
\hline Material support & -0.13 & 0.29 & -.42 & -0.44 & .659 \\
\hline Support from family and friends & 0.04 & 0.23 & .02 & 0.16 & .872 \\
\hline Support from medical personnel & 0.36 & 0.22 & .16 & 1.63 & .104 \\
\hline Satisfaction with life & -0.10 & 0.05 & -.09 & -1.98 & .048 \\
\hline Self-esteem & -0.58 & 0.07 & -.35 & -7.77 & $<.001$ \\
\hline Anxiety & 0.17 & 0.09 & .08 & 1.78 & .076 \\
\hline Depression & 0.34 & 0.10 & .20 & 3.48 & .001 \\
\hline Irritation & 0.17 & 0.30 & .02 & 0.57 & .567 \\
\hline
\end{tabular}

sively devoted to solving their problem of infertility (Dembińska, 2012). Statistically significant differences in the levels of social support were also identified depending on the infertility factor and the type of infertility. The highest level of support, in general and in individual categories, was reported by women in the case of whom both partners were infertile. This "equal" division of the problem probably makes both partners feel engaged in the therapeutic process, and additionally takes away from them a sense of guilt or shame. It is also interesting that lower social support is perceived by women with secondary infertility, i.e. those who already have a child, but struggle with conceiving another one. Society exerts more pressure on couples who are childless; therefore such couples can count on more social support than those trying to have more offspring. These results are especially interesting when compared with conclusions from the research conducted by Redo and Bielawska-Batorowicz (2014), devoted to expectations of infertile 
couples about the medical personnel. It turned out that such expectations do not depend on the time or method of treatment or on the infertility type. Therefore, we may assume that the reasons for the herein identified differences in perception of social support in the studied groups of women treated for infertility lie not in their diverse expectations, but in society treating those women differently.

A crucial issue related to psychological aspects of infertility treatment is the emotional state of the patients. In this study the levels of anxiety, depression, irritation and hope were analyzed. All three negative emotional states, i.e. anxiety, depression and irritation, are predictors influencing (lowering) life satisfaction of women struggling with infertility. The strongest of these predictors is depression, which is also a factor lowering the acceptance of one's own infertility.

The analysis revealed interesting relations between irritation and other variables. It turned out that it positively correlated with self-esteem and negatively with the depression level. Therefore, from the point of view of psychological help, irritation is a symptom that facilitates the coping process. It is a sort of motivational force, a sign of belief in one's capability to change the situation - after all, the higher the hope, the greater the anxiety. It is a variable standing in contradiction to anxiety and depression - which negatively correlate with self-esteem and hope, and negatively affects the satisfaction with life. It is also connected with the acceptance of one's own infertility - whereas a high depression level results in lower acceptance.

The analyses conducted by the author did not identify statistically significant differences in the interviewed women's emotional state depending on the selected sociodemographic variables. This outcome contrasts with some of the studies known from the literature on the subject, where such differences were found. For instance, in the study of Domar, Broome, Zuttermeister, Seibel, \& Friedman (1992) the depression level in women from marriages with the so-called male infertility factor was the same as in women from marriages with the female factor. It is contradictory to the studies of Edelmann and Connolly (1986), which revealed that women from marriages burdened by female infertility showed increased symptoms of depression, while those from marriages where the male partner was infertile were inclined to bursts of anger directed at their husbands.

Time since the diagnosis had a significant influence on the depression level in women - the most intense symptoms were displayed by patients who were diagnosed with infertility 2-3 years ago. The symptoms were less pronounced in women struggling with this illness for one year or for $6+$ years (Domar et al., 1992; cf. Hsu \& Kuo, 2002). Kee et al. (2000) found that patients using the in vitro method showed fewer symptoms of depression in the course of the illness than those only starting using assisted reproduction methods. Women and their husbands with primary infertility (i.e. women who have never been pregnant and cannot become pregnant) were more prone to depression symptoms than women with secondary infertility (Epstein \& Resenberg, 2005). Drosdzol and Skrzypulec (2009) identified the following risk factors of depression and anxiety for infertile patients: being female, age over 30, low education level, no professional activity, diagnosed male infertility, and being infertile for 3-6 years. Moreover, the author's pilot studies concerning psychological costs also revealed statistically significant differences on the basis of method and treatment time (Dembińska, 2014a). As for other psychological variables, such as satisfaction with life, acceptance of one's own infertility and self-esteem, their levels did not depend on the treatment methods, time since diagnosis and time of treatment. One should try to fathom the reason behind the contradictory results of the studies. Undoubtedly, a clear difference between the present studies and the pilot studies is a different methodology. In the pilot study the author created an original Psychological Costs in Infertility Scale which was based on qualitative studies. The items of this scale were taken directly from interviews with women struggling with infertility (Dembińska, 2014a). On the other hand, methods used in the studies described in the literature included mostly tools standardized for the whole population and available in broad psychological diagnosis. These contradictory results make it only natural to form a hypothesis that researchers studying groups with specific problems should construct dedicated research tools with questions adapted to the peculiarity of such groups. Such tools are more sensitive to differences in the studied group.

The conducted analyses revealed that predictors influencing the life satisfaction of patients treated for infertility are self-esteem and acceptance of one's own infertility (apart from the already mentioned emotional state - anxiety, depression, irritation). It was found that the higher the self-esteem and acceptance of one's own infertility, the higher the satisfaction with life. Variables influencing the acceptance of one's own infertility, treated as a kind of satisfaction with the area of life that encompasses experiencing procreation problems (cf. Dembińska, 2014b), include, apart from the depression level, self-esteem and satisfaction with life.

\section{CONCLUSIONS}

Undoubtedly, long-term and very physically, psychologically and economically burdening infertility treatment procedures, especially assisted reproduction methods, result in manifold consequences and
Psychological determinants of life satisfaction in women undergoing infertility treatment 
influence the patients' satisfaction with life. Knowledge of these determinants is extremely valuable for medical personnel conducting treatments, because, according to many studies, the psychological state of women suffering from procreation problems is connected not only with effectiveness of the used procedures, but mostly with psychological support provided for such women.
Aleksandra Anna Dembińska
Alesi, R. (2005). Infertility and its treatment - an emotional roller coaster. Australian Family Physician, 34, 135-138.

Baldur-Felskov, B., Kjaer, S. K., Albieri, V., StedingJessen, M., Kjaer, T., Johansen, C., Dalton, S. O., \& Jensen, A. (2012). Psychiatric disorders in women with fertility problems: results from a large Danish register-based cohort study. Human Reproduction, 28, 683-690.

Beisert, M. (1992). Psychologiczne skutki zaburzeń w pełnieniu małżeńskiej funkcji prokreacyjnej. [Psychological outcomes of marital reproductive failure]. In E. Bielawska-Batorowicz \& D. Kornas-Biela (eds.), Z zagadnień psychologii prokreacji [Reproductive psychology - selected issues] (pp. 117-144). Lublin: KUL.

Benyamini, Y., Gozlan, M., \& Kokia, E. (2005). Variability in the difficulties experienced by women undergoing infertility treatments. Fertility Sterility, 83, 275-283.

Bidzan, M. (2010). Psychologiczne aspekty nieptodności [Psychological aspects of infertility]. Kraków: Oficyna Wyd. „Impuls”.

Bielawska-Batorowicz, E. (1990). Psychologiczne aspekty rozpoznawania i leczenia niepłodności. [Psychological aspects of infertility diagnosis and treatment]. Ginekologia Polska, 61, 629-633.

Bielawska-Batorowicz, E. (1991). Psychologiczne aspekty niepłodności [Psychological aspects of infertility]. Przegląd Psychologiczny, 34, 103-119.

Bielawska-Batorowicz, E. (2006). Psychologiczne aspekty prokreacji [Psychological aspects of procreation]. Katowice: Wyd. Naukowe Śląsk.

Boivin, J., \& Takefman, J. E. (1995). Stress level across stages of in vitro fertilization in subsequently pregnant and non pregnant women. Fertility and Sterility, 64, 802-810.

Cousineau, T. M., \& Domar, A. (2007). Psychological impact of infertility. Best Practice \& Research Clinical Obstetrics \& Gynaecology, 21, 293-308.

De Berardis, D., Mazza, M., Marini, S., Del Nibletto, L., Serroni, N., Pino, M. C., Valchera, A., Ortolani, C., Ciarrocchi, F., Martinotti, G., \& Di Giannantonio, M. (2014). Psychopathology, emotional aspects and psychological counselling in infertility: a review. La Clinica Terapeutica, 165, 163-169.
Dembińska, A. (2012). Rola personelu medycznego we wsparciu kobiet poddawanych leczeniu niepłodności [The role of the medical staff in women's coping with infertility]. Medycyna Ogólna i Nauki o Zdrowiu, 4, 366-370.

Dembińska, A. (2013). Rola nadziei w pomocy psychologicznej kobietom leczącym niepłodność [The role of hope in psychological help for women undergoing infertility treatment]. Sztuka Leczenia, 1-2, 9-20.

Dembińska, A. (2014a). Psychological costs of life crisis in Polish women treated for infertility. Journal of Reproductive and Infant Psychology, 1, 96-107.

Dembińska A. (2014b). Akceptacja wtasnej nieptodności - kluczem skutecznego radzenia sobie? [Acceptance of one's own infertility - a successful coping strategy?], Bezdzietność jako problem wspótczesnego świata. Styl życia - niepłodność - adopcja [Infertility as a problem of the contemporary world. Style of life - infertility - adoption]. I Ogólnopolska Konferencja Interdyscyplinarna [The $1^{\text {st }}$ Polish Interdisciplinary Conference], Instytut Nauk o Rodzinie [Family Sciences Institute], Instytut Psychologii Uniwersytetu Opolskiego [Psychology Institute of the Opole University], Instytut Pedagogiki Uniwersytetu Wrocławskiego [Pedagogy Institute of the Wrocław University] and Wyższa Szkoła Pedagogiczna im. Janusza Korczaka w Warszawie [Janusz Korczak Pedagogical University in Warsaw], Kamień Śląski, 20-21 October.

Diener, E. (1984). Subjective well-being. Psychological Bulletin, 95, 542-575.

Diener, E., Emmons, R. A., Larson, R. J., \& Griffin, S. (1985). The Satisfaction With Life Scale. Journal of Personality Assessment, 49, 71-75.

Domar, A. D., Broome, A., Zuttermeister, P. C., Seibel, M., \& Friedman, R. (1992). The prevalence and predictability of depression in infertile woman. Fertility and Sterility, 58, 1158-1163.

Domar, A., Gordon, K., Garcia-Velasco, J., La Marca, A., Barriere, P., \& Beligotti, F. (2012). Understanding the perceptions of and emotional barriers to infertility treatment: a survey in four European countries. Human Reproduction, 27, 1073-1079.

Domar, A. D., Seibel, M. M., \& Benson, H. (1990). The mind/body program for infertility: a new behavioral treatment approach for women with infertility. Fertility and Sterility, 53, 246-249.

Donarelli, Z., Lo Coco, G., Gullo, S., Marino, A., Volpes, A., \& Allegra, A. (2012). Are attachment dimensions associated with infertility-related stress in couples undergoing their first IVF treatment? A study on the individual and cross-partner effect. Human Reproduction, 27, 3215-3225.

Drosdzol, A., \& Skrzypulec, V. (2009). Depression and anxiety among Polish infertile couples - an evaluative prevalence study. Journal of Psychosomatic Obstetrics and Gynaecology, 30, 11-20. 
Dzwonkowska, I., Lachowicz-Tabaczek, K., \& Łaguna, M. (2008). Samoocena i jej pomiar. Polska adaptacja skali SES M. Rosenberga [Self-esteem and its measuring. Polish version of $M$. Rosenberg's SES scale]. Warszawa: Pracownia Testów Psychologicznych.

Edelmann, R. J., \& Connolly, K. J. (1986). Psychological aspects of infertility. British Journal of Medical Psychology, 59, 209-219.

Epstein, Y. M., \& Rosenberg, H. S. (2005). Depression in primary versus secondary infertility egg recipients. Fertility and Sterility, 83, 1882-1884.

Freizinger, M., Franko, D. L., Dacey, M., Okun, B., \& Domar, A. D. (2010). The prevalence of eating disorders in infertile women. Fertility and Sterility, 93, 72-78.

Greil, A., Shreffer, K. M., Schmist, L., \& McQuillan, J. (2011). Variation in distress among women with infertility: evidence from population-based sample. Human Reproduction, 26, 2101-2112.

Holas, P., Radziwoń, M., \& Wójtowicz, M. (2002). Niepłodność a zaburzenia psychiczne [Infertility and Mental Disorders]. Psychiatria Polska, 36, 557-566.

Hsu, Y. L., \& Kuo, B. J. (2002). Evaluations of emotional reactions and coping behaviors as well as correlated factors for infertile couples receiving assisted reproductive technologies. Western Journal of Nursing, 10, 291-302.

Juczyński, Z. (2001). Narzędzia pomiaru w promocji i psychologii zdrowia [Measurement tools in health promotion and psychology]. Warszawa: Pracownia Testów Psychologicznych Polskiego Towarzystwa Psychologicznego.

Kahn, R. L. (1979). Age and social support. In M. W. Riley (ed.), Aging from birth to death: Interdisciplinary perspectives (pp. 77-91). Boulder, CO: Westview Press.

Kainz, K. (2001). The role of the psychologist in the evaluation and treatment of infertility. Woman's Health Issues, 6, 481-485.

Kalus, A. (2002). Bezdzietność w matżeństwie [Childlessness in marriage]. Opole: Wyd. Wydziału Teologicznego Uniwersytetu Opolskiego.

Kee, B. S., Jung, B. J., \& Lee, S. H. (2000). A study on psychological strain in IVF patients. Journal of Assisted Reproduction and Genetics, 17, 445-448.

Khademi, A., Alleyassin, A., Aghahosseini, M., Ramezanzadeh, F., \& Abhari, A. A. (2005). Pretreatment Beck Depression Inventory score is an important predictor for post-treatment score in infertile patients: a before-after study. BMC Psychiatry, 5, 25.

Klimek, R. (1995). Niepłodność uleczalna czy nie? [Infertility - Treated or Not?]. Warszawa: PZWL.

Lazarus, R. S. (1994). Universal antecedents of emotions. In P. Ekman \& R. J. Davidson (eds.), The nature of emotion: Fundamental question (pp. 19632171). New York: Oxford University Press.
Lopes, V. M., \& Leal, I. M. (2012). Personality and emotional adjustment in infertility. Journal of Reproductive Medicine, 57, 153-158.

Lund, R., Sejbaek, C. S., Christensen, U., \& Schmidt, L. (2009). The impact of social relations on the incidence of severe depressive symptoms among infertile women and men. Human Reproduction, 24, 2810-2820.

Łuczak-Wawrzyniak, J., \& Pisarski, T. (1997). Psychologiczne problemy w leczeniu niepłodności [Psychological problems in infertility treatment]. In T. Pisarski \& M. Szamatowicz (eds.), Nieptodność [Infertility] (pp. 298-304). Warszawa: PZWL.

Majkowicz, M., \& Chojnacka-Szawłowska, G. (1994). Metodologiczne problemy badania jakości życia [Methodological problems in quality of life measurement]. In de Walden-Gałuszko, K. \& Majkowicz, M. (eds.), Jakość życia w chorobie nowotworowej [Quality of life in cancer patients] (pp. 84-147). Gdańsk: Wydawnictwo Uniwersytetu Gdańskiego.

Menning, R. E. (1980). Infertility: A Guide for the Childless Couple. Austria: Furgal Media Corporation.

Mindes, E., Ingram, J. K. M., Kliewer, W., \& James, C. A. (2003). Longitudinal analyses of the relationship between unsupportive social interactions and psychological adjustment among women with fertility problems. Social Science \& Medicine, 56, 2165-2180.

Nelson, C. J., Shindel, A. W., Naughton, C. K., Ohebshalom, M., \& Mulhall, J. P. (2008). Prevalence and predictors of sexual problems, relationship stress, and depression in female partners of infertile couples. Journal of Sexual Medicine, 5, 1907-1914.

Noorbala, A. A., Ramezanzadeh, F., Abedinia, N., \& Naghizadeh, M. M. (2009). Psychiatric disorders among infertile and fertile women. Social Psychiatry and Psychiatric Epidemiology, 44, 587-591.

Noorbala, A. A., Ramazanzadeh, F., Malekafzali, H., Abedinia, N., Forooshani, A. R., Shariat, M., \& Jafarabadi, M. (2008). Effects of a psychological intervention on depression in infertile couples. The International Journal of Gynecology \& Obstetrics, 101, 248-252.

Pavot, W., \& Diener, E. (1993). Review of the Satisfaction with Life Scale. Psychological Assessment, 5, 164-172.

Ramezanzadeh, F., Aghssa, M. M., Jafarabadi, M., \& Zayeri, F. (2006). Alterations of sexual desire and satisfaction in male partners of infertile couples. Fertility and Sterility, 85, 139-143.

Ratajczak, Z. (1989). Psychologiczne koszty pracy a podmiotowość człowieka [Psychological costs of work and human subjectiveness]. In Z. Ratajczak (ed.), Psychologiczne koszty aktywności człowieka [Psychological costs of human activity] (pp. 162176). Katowice: Wyd. Uniwersytetu Śląskiego.

Ratajczak, Z. (1998). Psychologiczne koszty radzenia sobie w sytuacji utraty pracy [Psychological
Psychological determinants of life satisfaction in women undergoing infertility treatment 
Aleksandra Anna Dembińska costs of coping with job loss]. In Z. Ratajczak, (ed.), Bezrobocie. Strategie zaradcze i wzorce pomocy psychologicznej [Unemployment. Remedial strategies and patterns of psychological help] (pp. 13-19). Katowice: Wyd. Uniwersytetu Śląskiego.

Ratajczak, Z. (2000): Stres - koszty psychologiczne radzenie sobie [Stress - psychological costs - coping] In I. Heszen-Niejodek \& Z. Ratajczak (eds.), Człowiek w sytuacji stresu. Problemy teoretyczne i metodologiczne [Human in a stressful situation. Theoretical and methodological problems] (pp. 65-87). Katowice: Wyd. Uniwersytetu Śląskiego.

Ratajczak, Z. (2001). Oblicza ludzkiej zaradności [Faces of human resourcefulness] In K. Popiołek (ed.), Człowiek w sytuacji zagrożenia. Kryzysy, katastrofy, kataklizmy [Human in a life-threating situation. Crises, catastrophes and disasters] (pp. 15-22). Poznań: SPiA.

Ratajczak, Z. (2007). Psychologia pracy i organizacji [Work and organizational psychology]. Warszawa: Wyd. Naukowe PWN.

Redo, K., \& Bielawska-Batorowicz, E. (2014). Expectations towards medical personnel - a study with infertility clinic patients. Health Psychology Report, 2, 218-226.

Sbaragli, C., Morgante, G., Goracci, A., Hofkens, T., De Leo, V., \& Castrogiovanni, P. (2008). Infertility and psychiatric morbidity. Fertility and Sterility, 90, 2107-2111.

Sęk, H. (1986). Wsparcie społeczne - co zrobić, aby się stało pojęciem naukowym? [Psychological support - what should we do to make it a scientific term?]. Przeglad Psychologiczny, 3, 191-199.

Sęk, H. (1993). Wybrane zagadnienia psychoprofilaktyki [Selected issues of psychological prevention] In H. Sęk (ed.), Spoteczna psychologia kliniczna [Social clinical psychology] (pp. 472-503). Warszawa: PWN.

Shin, D. C., \& Johanson, D. M. (1978). Avowed happiness as an overall assessment of the quality of life. Social Indicators Research, 5, 475-492.

Trzeciakowska, A. (2003). Wybrane zagadnienia psychologiczne związane $\mathrm{z}$ procesem leczenia niepłodności technikami wspomaganego rozrodu [Selected psychological issues associated with the process of infertility treatment with the use of assisted reproductive technology] In J. Gadzinowski, L. Pawelczyk, \& J. Wiśniewski (eds.), Dawanie życia: problem wspomaganego rozrodu [Giving life: problems of assisted reproductive techniques] (pp. 47-53). Poznań: Wyd. UAM.

Verhaak, C. M., Smeenk, J. M., Eugster, A., van Minnen, A., Kremer, J. A., \& Kraaimaat, F. W. (2001). Stress and marital satisfaction among women before and after their first cycle of in vitro fertilization and intracytoplasmic sperm injection. Fertility and Sterility, 76, 525-531.
Weiss, P., Mateju L., \& Urbanek, V. (2004). Personality and characteristics of couples in infertile marriage. Ceska Gynekologie, 69, 42-47.

Whiteford, M. L., \& Gonzales, L. (1995). Stigma: the hidden burden of infertility. Social Science \& Medicine, 40, 27-36.

Wischamann, T., Stammer, H., Scherg, H., Gerhard, I., \& Verres, R. (2001). Psychosocial characteristics of infertile couples: a study by the Heidelberg Fertility Consultation Service. Human Reproduction, 16, 1753-1761. 